This item is the archived peer-reviewed author-version of:

\title{
Policymaking from a gender+ equality perspective
}

\section{Reference:}

Lombardo Emanuela, Meier Petra, Verloo Mieke.- Policymaking from a gender+ equality perspective Journal of women, politics \& policy - ISSN 1554-477X - 38:1(2017), p. 1-19

Full text (Publisher's DOI): http://dx.doi.org/doi:10.1080/1554477X.2016.1198206

To cite this reference: http://hdl.handle.net/10067/1353600151162165141 


\title{
Policymaking from a gender+ equality perspective
}

Emanuela Lombardo, Petra Meier, Mieke Verloo

Madrid Complutense University, University of Antwerp, Radboud University

\section{Short title}

Policymaking from a gender+ equality perspective

\begin{abstract}
This article discusses policymaking from a gender+ equality perspective. It connects the knowledge from various subfields - ranging from development planning, to feminist policy studies, to works on gender mainstreaming. By connecting different but convergent feminist sub-disciplines, it draws a picture of the field of gender+ and policymaking. The literature review includes works in political science and administration, policy studies, feminist economics, and legal studies. By delineating the boundaries of research on gender and policymaking, the article addresses existing challenges and reflects on gaps and promising terrains of study that could further develop and establish the field of feminist policy studies.
\end{abstract}

\section{Key words}

Policymaking; feminist policy studies; gender equality policies; intersectionality; gender mainstreaming. 


\section{Introduction}

The aim of this Special Issue is that of discussing policymaking from a gender+ equality perspective $^{\mathrm{i}}$. Policymaking comprises the articulation of social issues as political problems, policy formulation, adoption, implementation, monitoring and evaluation. Policymaking is an ongoing process of preparing, executing, and evaluating interventions by state actors, at different levels of government, including the establishment of institutions, to define the rules steering society. Gender perspectives have challenged policy studies by exposing the lack of neutrality of policymaking and of studying policymaking, similar to the way in which scholars working on class, ethnicity, or sexual orientation have shown that policymaking is not only gender- but also class-, ethnicityand sexuality-biased. As a result of the interventions by state actors or attempts at it, it is argued, existing inequalities across all domains are affected in their nature or degree. Put shortly, policies can indeed counteract inequality, and often they are meant to do so, but they can also produce or reproduce it.

Over time, a growing number of scholars, coming from a broad range of disciplines, studies specific policy fields such as childcare, domestic violence, healthcare, labor market policies, reproductive rights policies, social policies, or the welfare state, investigating the gender+ inequalities (re)produced or contested in these sectors. While similarly to Mazur (2002) we opt to call this field feminist policy studies, this research adopts a variety of perspectives. Scholars come from as different fields as European studies, economics, law, public administration or geography, and take as different epistemological perspectives such as positivist and constructivist ones. What they share is a concern of what making policies means in terms of a gender+ equality perspective. But 
then still the foci of the various scholars range from an eye on women, through a gender perspective, to the deconstruction of gender, and a focus on intersectionality. Similarly, there are different usages of the concept 'gender', as a synonym of the sociodemographic variable of sex, or as a socially and historically constructed relation. In this article we opt for the use of 'gender+', to recognize that gender is always intersected by other axes of inequality. While not taking all of them explicitly into account, we wish not to lose sight of them.

This Special Issue more particularly focuses on exploring the actual 'making' of policies from a gender+ perspective. Rather than being oriented towards the 'output' of the policy making process, this Special Issue analyzes the 'process' in itself, and reflects on what a gender+ lens teaches us about policymaking. The question is what challenges does a gender+ approach pose to the process of 'making' policies and thereby tell us for better understanding of it?

In this introduction we review the field of feminist studies focusing on policymaking by linking the knowledge from various sub-disciplines. To this end this article is organized around a number of topics that loosely follow the chronological development of the field of feminist policy studies. The literature review expands and builds on earlier overviews of feminist policy studies (Hawkesworth 1994; Mazey 2000; Mazur 2002; Mazur and Pollack 2009; Orloff and Palier 2009), draws from a broad range of articles in political science, policy studies, public administration, as well as feminist economics and legal studies. Thereby this article introduces the four contributions of this Special Issue, each broadening our understanding of what implications (the study of) policymaking can have for a gender+ equality perspective. 


\section{Bringing Women/Gender In}

A gender analysis of policymaking can be drawn back to the 1970s, when feminists from a broad variety of disciplines started criticizing the absence of women in development planning. They tackled the presumed gender roles and unitary character of the household, and the unilateral focus on the formal economy (Boserup 1970; Benería and Roldán 1987; Dwyer and Bruce 1988). The then dominant focus on 'Women in development', targeting family and welfare policies (Kabeer 1994), ignored the productive role of women (in the formal and informal economy), often redirected production means from women to men (Agarwal 1981; Shiva 1989), disregarded the specific interests women have (Molyneux 1985), and actually worsened the position of women and the power balance between the sexes (Rao, Anderson, and Overholt 1991; Tinker and Bramsen 1976; Lycklama à Nijeholt 1987).

This literature pointed at the failures in the design, implementation, evaluation, and effects of development policies, due to its male bias (Elson 1995b; Jahan 1995). Consequently, it underlined the need to decompose household patterns and to consider the roles of women beyond stereotypes (Benería 2003; Jaquette and Summerfield 2006). Only so could these programs foster development, but-especially-empower women (Tinker 1990; Molyneux and Razavi 2003). Feminist scholars and policymakers in international organizations or development NGOs suggested alternative planning, evaluation and management strategies sensitive to gender (Jain 1983; Overholt et al. 1985; Sen and Grown 1988; Moser 1993). This literature not only made a diagnosis of what went wrong in development planning but also put forward a prescription of what to 
do. This prescriptive component is especially interesting since it is one of the pillars of later trends in feminist policy studies such as gender impact assessment, gender budgeting, gender evaluations, and gender mainstreaming.

\section{Feminist Issues and State Politics}

A significant proportion of the feminist policy literature analyzes the responsiveness of political systems to feminist requests, studying the extent to which feminist ideas, needs, and interests get tackled by policies. Important in this literature are critical success factors, the conditions under which states and institutions adopt and pursue womenfriendly, gender-balanced or feminist policies (Stetson and Mazur 1995; Outshoorn and Kantola 2007).

Hawkesworth (1994), in her review of feminist policy studies, discusses American works. These studies find that the creation of feminist policy networks of grassroots and organized women and the use of a nondiscrimination strategy had been crucial so as to get feminist ideas, needs and interests on the political agenda. Yet they diverge in the assessment of equality strategies to gender policymaking. Freeman (1975) criticizes the limitations of the reformist nondiscrimination strategy in challenging male-entrenched privileges, while Gelb and Palley (1996), Boneparth (1982), and Stetson (2004) praise the advantage of a reformist policy that might achieve some results precisely because it is not explicitly threatening male power.

The Research Network on Gender Politics and the State (RNGS) explored comparatively the extent to which women's policy agencies (Stetson and Mazur 1995) in Western postindustrial democracies pursue women's interests (Mazur 2002; Outshoorn 2004; 
Lovenduski 2005; Haussman and Sauer 2007). Employing a comparative methodology for a longitudinal analysis of selected policy debates across countries, these studies center on the agenda-setting and adoption stages of the policy-making process, analyzing the role, position, and scope of women's policy agencies. McBride and Mazur's (2010) study shows that women's policy agencies matter to the women's movement, since the more active the agencies are the more likely the state responses reflect the women's movement goals.

European Union (EU) - and federal - policy processes offer a good case to observe how and why feminist ideas are incorporated in policymaking, since the multitiered dimension of EU governance creates opportunities and constraints at different levels and for a variety of institutional and civil society actors. Van der Vleuten's (2007) pincers' model explains the adoption and implementation of EU gender equality policies in the memberstates thank to the action of actors that squeeze unwilling states from below and from within, through the mobilization of domestic feminist and nonfeminist actors, and from above, through the action of supranational institutions such as the European Commission and the European Court of Justice. The model expands the discussion by Hoskyns (1996), who links success in the implementation of EU gender policy with the EU responsiveness to the demands of the women's movements at the domestic level.

Walby (2009) looks at systems more broadly, and reflects on success factors in gendering policymaking by developing a model that pays attention to the complexity and intersectionality of inequality regimes, such as gender, class, and ethnicity within institutional domains such as the economy, polity, violence, and civil society. Change in the systems is caused not only by negative feedback loops but also by positive ones. For 
example, Walby argues that the early Swedish success in gendering policymaking began when the percentage of women in decision making reached more than 40 percent, as this change destabilized the system and caused the incorporation of women's needs in the political agenda.

Other scholars look into broader structural and contextual features, such as the role of macro level institutional features and more contingent political factors (Zippel 2006; Franceschet 2010; Htun and Weldon 2010), dictatorships and democracies (Tripp 2013), processes of democratization (Waylen 2007; Rai 2008; Walby 2009), or legacies of former communist regimes (Saxonberg and Sirovatka 2006). Others focus on economic parameters and ideological factors as hindering feminist success (Kaplan 1992), promoting care policies (Morgan and Zippel 2003), or copying policies from other contexts (Gornick and Meyers 2003). They reveal how processes of economic liberalization have led to structural adjustment policies that have provoked cuts in state spending on welfare, health, and education, which have negatively affected women while increasing the care burden for women due to the reduction of state provisions (Elson 1995a; Mahon and Michel 2002; Dobrowolsky 2009; Fraser 2009). Of relevance in this context is also the feminist literature on the role of the welfare state in shaping women's lives and promoting or hammering gender equality (Orloff 1996, 2009).

\section{The Male Bias in the Policy Context and its Construction}

Apart from studying critical success factors for promoting gender equality, feminist scholars also explore the male bias of the policy context and process. Institutions are pervaded by a "deeply embedded culture of masculinity" (Lovenduski 2005, 48; Rai 
2010); public policies, law, bureaucratic and organizational practices, political and economic processes tend to reproduce the male norm masqueraded as "neutral" and to systematically disadvantage women (Jones and Jonasdottir 1988; Savage and Witz 1992; Rees 1998; Shaw 2000). The androcentrism of policymaking suggests that institutions, their processes, and policies thereby reinforce a male power advantage (Hawkesworth 1994, 105).

Examples of gender-biased policies and their gendered implications abound. Welfare policies that differentiate the type of benefits for employed and nonemployed people, granting pension rights only to the former or penalizing interruptions in the participation in the labor market or part-time schemes, tend to perpetuate a male breadwinner-female caregiver model that increases women's dependence from the male partner and promotes the feminization of poverty (Hawkesworth 1985; Sapiro 1986; Fraser 1989; Orloff 1996; Sainsbury 1996; Orloff, O’Connor, and Shaver 1999; Meyers, Gornick, and Peck 2001; Johnson, Duerst-Lahti, and Norton 2007). Public child-care and parental leave policies may have adverse effects on the employment patterns of women (Gornick 2006, 2007). Lower-class, often migrant, women, working in the care -frequently informal- economy are especially penalized by welfare policies that tend to perpetuate hierarchical relations both between men and women and among women (Ehrenreich and Hochschild 2002).

While the literature discussed so far takes women's interests for granted, discursive approaches studying the content of policies suggest that such interests are constructed within policy processes. This paradigmatic shift can be attributed to Carol Bacchi's $(1999,66)$ "what's the problem? represented to be approach." Policies, she argues, assume particular interpretations of what is the problem at stake. The approach focuses 
on gaps and absences in policy discourse by asking "what is left unproblematized," thereby uncovering the norms embedded in particular constructions, which reflect takenfor-granted beliefs and hegemonic assumptions. This has contributed to an understanding of how there can be slow or no progress in policies designed to foster gender+ equality. Drawing on Bacchi's (1999) approach, the discursive feminist policy literature has developed within European comparative research projects such as Mainstreaming Gender Equality in Europe (MAGEEQ) and Quality in Gender+ Equality Policies (QUING). The development of a specific methodology, critical frame analysis, has enabled researchers to make the interpretative and normative content of policy documents explicit, by identifying the diagnosis of the problem, the solutions proposed, the roles assigned to actors, the gender and intersectional dimensions, and the norms and mechanisms involved in the construction of a policy issue (Verloo 2007; Lombardo, Meier and Verloo 2009).

This scholarship has contributed to explore processes of contestation and attribution of meanings to gender equality, during which the concept can be stretched to incorporate new meanings (for instance, when gender equality is conceived as intersecting with other inequalities), shrunk (into nondiscrimination in a strictly legal sense), or bent to other goals than that of gender equality (such as economic growth) to fit into existing policy frames (Lombardo, Meier, and Verloo 2009). Further developments (Ferree et al. 2002; Ferree 2012; 2009a, 2009b) have shown that different meanings of gender+ equality policies are rooted in different historical understandings of inequality and have developed frameworks to understand why policies are framed the way they are (Verloo and Walby 2010). Other analyses have explored the shifts in the meaning/content of gender policies 
through the years, such as EU (Stratigaki 2004; Lewis 2006; Lombardo and Meier 2008; Knijn and Smit 2009) or the Organization for Economic Co-operation and Development (OECD; Mahon 2009) discourses on reconciliation policies.

International relations' constructivist approaches have focused on processes of norms making, legitimating, and diffusion by looking at the different levels of governance (Elgstrom 2000; True and Mintrom 2001). More recently this literature connects to the literature discussed in the previous section, analyzing how discursive and material opportunities and political dynamics are linked to gender+ equality progress in policymaking (Bacchi 2004; Ferree 2012; Hafner-Burton and Pollack 2000; Krizsan and Popa 2010; Lombardo and Forest 2012; Verloo and Walby 2010).

\section{Mainstreaming Gender into Policymaking}

To challenge the false gender neutrality of policymaking, feminists have devised strategies to mainstream gender equality into policymaking. This incorporation of a gender perspective into policymaking has generated a variety of "productive tensions in theory and practice," as Walby $(2005,321)$ argues. It has been conceptualized according to different quality criteria (Lombardo 2005; Lombardo and Meier 2006) and different visions of equality, such as inclusion (connected to equal treatment), difference (linked to positive actions), and transformation of existing gender roles and policy practices, that mainstreaming has been expected to deliver (Rees 1998; Verloo 2001; Squires 2005; Walby 2005).

Borrowing concepts from development studies, where mainstreaming first emerged, feminist scholars have identified different political approaches. Jahan (1995), in 
development studies, distinguishes between integrationist and agenda-setting approaches. Integrationist approaches introduce a gender perspective into existing policy paradigms, which has been associated with more technocratic applications of mainstreaming (Verloo 2005) and the inclusion of gender experts in policy machineries (Barnett-Donaghy 2004a; Rees 2005). Agenda-setting approaches transform existing policy paradigms, by changing decision-making structures and processes, prioritizing gender objectives among competing issues, reorienting the mainstream political agenda, and rearticulating policy ends and means from a gender perspective. This has been associated with more participatory forms of mainstreaming, as in the case of Northern Ireland (Barnett-Donaghy 2004b).

To reorganize policy processes and mechanisms from a gender perspective, gender experts and practitioners have devised a variety of policy tools, often employed in development planning. They have designed gender impact assessments (Verloo and Roggeband 1996; Woodward and Meier 1998) to make visible the effect of policies on gender inequalities, and elaborated tools to analyze budgets from a gender perspective (Elson 1999, 2004; Budlender 2000; Budlender, Sharp, and Allen 1998; Budlender et al. 2002). Another rising practice is the training of civil servants and politicians (Frey et al. 2006).

Recently, there has been attention for the weakening of the support for gender mainstreaming across Europe, which shows in standstills in accountability measures and sanctions connected to existing promises to deploy the strategy, and a breaking down of institutional arrangements, including in policymaking to respond to the economic crisis (Bettio et al 2012; Smith and Villa 2010). Also, studies showed that the introduction of 
gender mainstreaming risked the dilution of gender expertise and dismantling of equality institutions, based on the mistaken assumption that gender equality is already in the mainstream (Hafner-Burton and Pollack 2000; Mazey 2002). Among the reasons for the slow development and ineffective implementation of this strategy the following have emerged. The co-existence of competing definitions and multiple meanings of gender mainstreaming make it difficult to see how gender mainstreaming could be implemented and to assess what it is actually implemented (Rees 1998; Mazey 2000; Verloo 2005). The strategy is also based on voluntaristic efforts rather than binding commitments (Behning and Serrano 2001; Verloo 2005; Walby 2005) so that it becomes “everybody's—and nobody's-—responsibility” (Mazey 2002, 228).

A key weakness of the implementation of gender mainstreaming is the lack of specific governmental bodies responsible for monitoring the application of mainstreaming initiatives (Beveridge et al. 2000). The consolidation of femocrats and the participation of gender experts in the policy process (Woodward 2003) is key to ensure that policymaking is based on "gendered" knowledge (Beveridge and Nott 2002; Squires 2005). A favorable context for a successful implementation of gender mainstreaming seems to require a high level of gender equality awareness among policymakers who are not gender experts (Verloo 2001; Woodward 2003; Walby 2005). The voluntary basis of mainstreaming and the limited resources and power of gender experts and NGOs who support its implementation can do little to contrast civil servants' resistance to apply the gender tool. The organizational characteristics affecting public policy implementation in general promote a more integrationist and expert-bureaucratic type of mainstreaming (McGauran 2009). It seems that gender mainstreaming cannot "escape the genderedness of 
organizations," such as Ministries (Benschop and Verloo 2006, 20), due to the fact that power differences between the business and the feminist agendas determine compromises that hinder the transformative potential of mainstreaming. Experiences of mainstreaming gender into different sectors, from agriculture (Pruegl 2009) to development (Subrahmanian 2004), reveal cooptation of feminist goals by policymakers due to power mechanisms (Stratigaki 2005). As Mazey (2000, 343) states, since gendering policymaking requires a critical review of policymakers' conceptualization of policy problems, "change will entail questioning of deeply embedded cultural values and policy frames, supported by institutions and powerful advocacy coalitions.”

\section{Recent Feminist Approaches to Policymaking}

Although gender targets, tools, and data developed as part of the mainstreaming strategy are crucial for the promotion of gender equality (Villagómez 2004), scholars have also denounced the pitfalls of the "gender tools business" for the depoliticization of a feminist project. The governmental use of gender impact assessment, statistical data, benchmarks, targets, and indicators might turn into a toolkit approach, where it is assumed that gender equality will be achieved through the compliance of procedures, thereby losing the power dimension of the gender struggle (Currie 1999) and leaving the prevailing unequal gender relations untouched (Mukhopadhyay 2004; Tiessen 2005). A reason suggested for this technicalization of gender is that it is easier for gender advocates to sell and for policymakers to accept a view of gender mainstreaming based on a neutral toolkit rather than on feminist premises, such as the challenging of power hierarchies and a radical questioning of policy processes and actors (Lombardo and Meier 2006). Stratigaki (2005) 
similarly claims that barriers to gender mainstreaming in the EU are due to the patriarchal opposition to feminist goals implied in the strategy. The diffusion of a technocratic model of gender mainstreaming where bureaucrats, and sometimes experts, are the main actors helps to understand the prevalent spreading of the toolkit model (Verloo 2005). Other scholars focus on the intentionality and rationality inherent in the definition of gender mainstreaming as contributing to a toolkit model (Meier and Celis 2011). On the whole, this literature on the politicization of the strategy of mainstreaming contributes to an understanding of policymaking as essentially political.

A new development in equal treatment policies, which has not been much reflected in gender mainstreaming literature, is the growing attention to multiple discrimination and the legal institutionalization of equal treatment across a wider range of inequality axes, combined with shifts in the institutional architecture of antidiscrimination bodies toward integrated bodies addressing multiple discrimination (Kantola and Nouisiainen 2009; Krizsan et al. 2012). These developments are established as "gender+" equality policies, assuming that working toward gender equality is only possible if the intersectionality of gender with other axes of inequality is integrated. This is, for instance, the case of studies that criticize policies, as in Sweden, which give access to assisted reproduction to both homosexual and heterosexual couples, but deny this right to any single (Kvist, Carbin, and Harjunen 2009).

Other innovating approaches explaining the success or failure of policymaking that promotes gender+ equality combine elements of political opportunity structures, mobilizing networks, and framing dynamics, including strategic framing. The impulse to this has been given by Hafner-Burton and Pollack (2000), who apply a social movement 
theory approach to analyze the application of gender mainstreaming in five areas of EU policy. They argue that three factors can explain the implementation of gender mainstreaming to avoid potential resistance from policymakers that are more market oriented: political opportunities opened by EU institutions; networks of gender advocates; and the strategic framing of gender mainstreaming to make it fit with the dominant frame of a given directorate general.

Alliances and forums have also been suggested as ways to successfully mainstream gender into policymaking. Despite the dangers of co-option of feminist agendas by the state, the collaboration of feminist activists and experts with state actors has been key to further gender equality goals (Subrahmanian 2004; Woodward 2004) but also difficult to implement (Meier 2007). Scholars in politics and development tend to agree that, to repoliticize gender, this collaboration needs to work toward the creation of spaces for the empowerment of the most marginalized so that they can express their voices (Fraser 1989; Mukhopadhyay 2004; Verloo 2005). Scholars show the relevance of velvet triangles of feminist bureaucrats, trusted academics, and the women's movement for implementing gender mainstreaming into policymaking (Lycklama à Nijeholt et al. 1988; Woodward 2004). There is also reflection on concepts of social and policy learning, thereby shifting the focus from political dynamics to socialization or knowledge transfer (Beveridge and Velluti 2008).

\section{What's next?}

Although the borders of feminist policy research are not as neatly defined, there is a lot of research on gender+ and policymaking from different fields and approaches, as the 
previous pages have shown. Whether the focus is placed more on the process or the content of policymaking, feminists have criticized the androcentric character of policymaking, showing that the way policies are made is not gender+ neutral but rather based on the male (heterosexual, white, or other) norm. Androcentric policymaking creates gendered categories of privileged and unprivileged people in which women (and other groups) are systematically disadvantaged. If the existence of male biases and norms is represented as the main problem with policymaking, feminists have suggested different ways for addressing the problem by enhancing gender+ equal processes and policies.

Development planning has been identified as the field where a gender+ analysis of policymaking first emerged, criticizing the absence of women in policymaking and proposing ways to gender development policies. The study of critical success factors that favor the entry of women's ideas into politics has been undertaken by numerous approaches, exemplified by the RNGS works, that have explored the gendering of policymaking at the agenda-setting, adoption, and implementation stages. If the former field has analyzed the process and actors of policymaking, discursive politics approaches, exemplified by the MAGEEQ and QUING research, have studied the construction of gender bias in the content of policymaking, thus focusing on the "making" of gender+ policies at the design and formulation stages of the process. At the level of policy strategies the challenging of gender+ biases in policymaking was more explicitly placed on the agenda through gender mainstreaming. The prescriptive part of the work on gender and policymaking on how policies should be done was then particularly developed through works on gender mainstreaming, gender impact assessment, or gender budgeting, thereby borrowing and further elaborating concepts and tools from development studies. 
Recent research on gender and policymaking has evolved in several directions, mainly focusing on the implementation of gender mainstreaming, with some works criticizing the pitfalls of a technocratic approach to mainstreaming and suggesting ways to empower women, while other works try to explain the successful or unsuccessful implementation of mainstreaming.

Yet, there remain many challenges. The gendered character of policymaking has been studied without a substantial challenge to the use of fixed gender categories. Carol Bacchi's article discusses what it means to talk about policies as gendering practices and how this enables forms of analysis that bypass categorical distinctions (e.g. 'women', 'men', 'gender', 'race'). It suggests a shift from considering how policies impact on women and men to asking how they constitute them in ways that can have gendering, racializing, heteronorming, or classing effects. It elaborates on the implications that accompany this shift in perspective - implications for thinking about policy, change, subjectivity and the role of the researcher and policymaker.

Other dimensions of the unequal character of policymaking could be further explored. Except for development planning, there are few feminist works addressing policymaking in areas that are not explicitly considered as gender-related areas, such as transport or agriculture. Also, not all phases of policymaking receive the same amount of attention. More research is also needed to explain why and to what extent there is progress in gender+ equal policymaking. Some studies set benchmarks and targets to assess progress in gender-equal policymaking or discuss how specific developments in gender+ equality such as women's inclusion in the labor market or in political representation can be considered as signs of progress (Walby 2009). Other scholars (Ferree 2009b) have shown 
how assessing progress in gender+ equality policies is context related and dependent on the specific institutional and discursive opportunities structure so that what appears as quality policymaking in Europe for instance does not necessarily apply to the US context. In other studies (Rai 2008; Fraser 2009) the focus is placed on how processes such as neoliberalism and globalization not only can have negative implications on gender+ equal policymaking but also are complexly intertwined with them. Yet more reflexive and empirical works on the quality criteria to assess progress in policymaking from a gender+ perspective would help to identify what are the chances for success of policy strategies that aim at furthering gender+ equal policymaking.

Rosalind Cavaghan brings new insights on understanding why gender mainstreaming is not implemented, exploring the mechanisms through which organizational nonengagement is constituted and how it can be challenged, in a unit of DG Research of the European Commission. Her analysis shows that the non-engagement of the unit was based on a "local gender knowledge" that excluded the possibility that any issues of gender inequality might be existing or relevant in the work of the unit. Alternative (scientific) knowledge that could have challenged this "local knowledge" was blocked because of loyalties to pre-existing practices and priorities. Her article thus offers elements for deepening our understanding of gendered change in the state and barriers to its achievement.

Amy Mazur makes a call for systematically studying, in a feminist comparative policy research tradition, the stages of the policy process that follow policy adoption: implementation, evaluation and outcomes. Drawing on research in both feminist and non feminist policy studies, she proposes an analytical construct for assessing whether 
feminist policies after they are formally adopted actually entail concrete practices and policies that effectively promote gender equality throughout society. Developing this analytical measurement constitutes, according to Mazur, the essential first step in the emerging research on feminist postadoption policy in a comparative perspective.

Maria Bustelo, in the final contribution of this Special Issue, argues that evaluation from a gender+ perspective is a key element for (re)gendering the policymaking process. While feminist scholars have challenged the neutrality of policymaking processes and outputs, evaluation has been less studied in policymaking literature than planning or implementation, so the implications of what it means to do evaluation from a gender perspective, contends Bustelo, remain to be thoughtfully explored. She explores the developments in conceiving evaluation from a gender+ perspective, and how both feminist (policy) studies and the evaluation field can fruitfully contribute to each other for developing theories and practices to (re)gender the policymaking process.

\section{References}

Agarwal, Bina. 1981. Water Resources Development and Rural Women. New Delhi: Ford Foundation.

Bacchi, Carol. 1999. Women, politics and Policies: The Construction of Policy Problems. London: Sage.

Bacchi, Carol. 2004. "Policy and Discourse: Challenging the Construction of Affirmative Action as Preferential Treatment." Journal of European Public Policy 11 (1): $128-46$. 
Barnett-Donaghy, Tahnya. 2004a. "Applications of Mainstreaming in Australia and Northern Ireland.” International Political Science Review 25 (4): 393-410.

Barnett-Donaghy, Tahnya. 2004b. "Mainstreaming: Northern Ireland's ParticipativeDemocratic Approach." Policy and Politics 32 (1): 49-62.

Behning, Ute, and Amparo Serrano. 2001. Gender Mainstreaming in the European Employment Strategy. Brussels: ETUI.

Benería, Lourdes. 2003. Gender, Development and Globalization: Economics as if All People Mattered. New York: Routledge.

Benschop, Yvonne, and Mieke Verloo. 2006. "Sisyphus' Sisters: Can Gender Mainstreaming Escape the Genderedness of Organizations?" Journal of Gender Studies 15 (1): 19-33.

Bettio, Francesca et al. 2012. The Impact of the Economic Crisis on the Situation of Women and Men and on Gender Equality Policies. Brussels: European Commission.

Beveridge, Fiona, and Sue Nott. 2002. "Mainstreaming: A Case for Optimism and Cynicism.” Feminist Legal Studies 10 (3-4): 299-311.

Beveridge, Fiona, and Samantha Velluti (eds.). 2008. Gender and the Open Method of Coordination: Perspectives on Law, Governance and Equality in the EU. Aldershot: Ashgate.

Boneparth, Ellen (ed.). 1982. Women, Power and Policy. New York: Pergamon.

Boserup, Ester. 1970. Woman's Role in Economic Development. London: Allen and Unwin. 
Budlender, Debbie. 2000. "The Political Economy of Women's Budgets in the South.” World Development 28 (7): 1365-78.

Budlender, Debbie, Diane Elson, Guy Hewitt, and Tanni Mukhopadhyay. 2002. Gender Budgets Make Cents: Understanding Gender Responsive Budgets. London: Commonwealth Secretariat.

Budlender, Debbie, Rhonda Sharp, and Kerry Allen. 1998. How to Do a GenderSensitive Budget Analysis: Contemporary Research and Practice. London: Australian Agency for International Development and Commonwealth Secretariat.

Currie, Dawn H. 1999. "Gender Analysis from the Standpoint of Women: The Radical Potential of Women's Studies in Development." Asian Journal of Women's Studies 5 (3): 9-44.

Dobrowolsky, Alexandra. 2009. Neoliberalism and After? Women and Public Policy in Canada: Continuity and Change. Oxford: Oxford University Press.

Dwyer, Daisy, and Judith Bruce (eds.). 1988. A Home Divided: Women and Income in the Third World. Stanford: Stanford University Press.

Ehrenreich, Barbara, and Arlie Russel Hochschild (eds.). 2002. Global Woman: Nannies, Maids and Sex Workers in the New Economy. London: Granta books.

Elgstrom, Ole. 2000. "Norm Negotiations: The Construction of New Norms Regarding Gender and Development in EU Foreign Aid Policy." Journal of European Public Policy 7 (3): 457-76.

Elson, Diane. 1995a. "Gender Awareness in Modeling Structural Adjustment". World Development 23 (11): 1851-68. 
Elson, Diane (ed.). 1995b. Male Bias in the Development Process. Manchester: Manchester University Press.

Elson, Diane. 1999. Gender Budget Initiative. London: Commonwealth Secretariat.

Elson, Diane. 2004. "Engendering Government Budgets in the Context of Globalization(s)." International Feminist Journal of Politics 6 (4): 623-42.

Ferree, Myra Marx. 2009a. "An American Roadmap to Equality? Framing Feminist Goals in a Liberal Landscape." In Gender equality: Transforming Family Divisions, eds. Janet Gornick and Marcia Meyers. New York: Polity Press, 283315.

Ferree, Myra Marx. 2009b. "Inequality, Intersectionality and the Politics of Discourse. Framing Feminist Alliances.” In The Discursive Politics of Gender Equality: Stretching, Bending and Policy-Making, eds. Emanuela Lombardo, Petra Meier, and Mieke Verloo. London: Routledge, 86-104.

Ferree, Myra Marx. 2012. Varieties of Feminism. German Gender Politics in Global Perspective. Stanford: Stanford University Press.

Ferree, Myra Marx, William Gamson, Jürgen Gerhards, and Dieter Rucht. 2002. Shaping Abortion Discourse: Democracy and the public Sphere in Germany and the United States. Cambridge: Cambridge University Press.

Franceschet, Susan. 2010. "Explaining Domestic Violence Policy Outcomes in Chile and Argentina." Latin American Politics and Society 52 (3): 1-29.

Fraser, Nancy. 1989. Unruly Practices: Power, Discourse and Gender in Contemporary Social Theory. Cambridge: Polity Press. 
Fraser, Nancy. 2009. "Feminism, Capitalism and the Cunning of History." New Left Review 56: 97-117.

Freeman, Jo. 1975. Women: A Feminist Perspective. Palo Alto, CA: Mayfield Publishing.

Frey, Regina, Jutta Hartmann, Andreas Heilmann, Thomas Kugler, Stephanie Nordt, and Sandra Smykalla. 2006. Gender Manifesto: A call for Critical Reflection on Gender-oriented Capacity Building and Consultancy. Available at http://www.gender.de/mainstreaming/GenderManifesto_engl.pdf

Gelb, Joyce, and Marian Lief Palley. 1996. Women and Public Policies: Reassessing Gender Politics. Charlottesville: University of Virginia Press.

Gornick, Janet C. (ed.). 2006. "Special Issue on Work-Family Reconciliation Policies: Theory and Practice." Journal of Comparative Policy Analysis: Research and Practice 8 (2): 99-205.

Gornick, Janet C. (ed.). 2007. "Special issue on Does Policy Matter? The Impact of Work-Family Reconciliation Policies on Workers and their Families." Journal of Comparative Policy Analysis: Research and Practice 9 (2): 111-214.

Gornick, Janet C., and Marcia K. Meyers. 2003. Families that Work: Policies for Reconciling Parenthood and Employment. New York: Russell Sage Foundation.

Hafner-Burton, Emilie, and Mark Pollack. 2000. "Mainstreaming Gender in the European Union." Journal of European Public Policy 7 (3): 432-56.

Haussman, Melissa, and Birgit Sauer (eds.). 2007. Gendering the State in the Age of Globalization. Lanham, MD: Rowman \& Littlefield.

Hawkesworth, Mary. 1985. "Workfare and the Imposition of Discipline." Social Theory and Practice 11 (2): 163-81. 
Hawkesworth, Mary. 1994. "Policy Studies within a Feminist Frame.” Policy Sciences 27 (2-3): 97-118.

Hoskyns, Catherine. 1996. Integrating Gender: Women, Law and Politics in the European Union. London: Verso.

Htun, Mala, and Laurel Weldon. 2010. “When Do Governments Promote Women's Rights? A Framework for the Comparative Analysis of Sex Equality Policies.” Perspectives on Politics 8 (1): 207-16.

Jahan, Rounaq. 1995. The Elusive Agenda: Mainstreaming Women in Development. London: Zed Books.

Jain, Devaki. 1983. Development as if Women Mattered or Can Women Build a New Paradigm? New Dehli: Institute of Social Studies Trust.

Jaquette, Jane, and Gale Summerfield (eds.). 2006. Women and Gender Equity in Development Theory and Practice. Durham, NC: Duke University Press.

Johnson, Cathy Marie, Georgia Duerst-Lahti, and Noelle H. Norton. 2007. Creating Gender: The Sexual Politics of Welfare Policy. Boulder: Lynne Rienner Publishers.

Jones, Kathleen B., and Anna Jonasdottir (eds.). 1988. The Political Interests of Gender: Developing Theory and Research with a Feminist Face. London: Sage.

Kabeer, Naila. 1994. Reversed Realities: Gender Hierarchies in Development Thought. London: Verso.

Kantola, Johanna, and Kevät Nousiainen (eds.). 2009. "Special Issue on Institutionalizing Intersectionality in Europe." International Feminist Journal of Politics 11 (4): $459-609$. 
Kaplan, Gisela. 1992. Contemporary Western European Feminism. New York: New York University Press.

Knijn, Trudie, and Arnoud Smit. 2009. "Investing, Facilitating, or Individualizing the Reconciliation of Work and Family Life: Three Paradigms and Ambivalent Policies." Social Politics 16 (4): 484-518.

Krizsan, Andrea, Hege Skeje, and Judith Squires (eds.). 2012. Institutionalizing Intersectionality. Basingstoke: Palgrave.

Kvist, Elin, Maria Carbin, and Hannele Harjunen. 2009. "Domestic Services or Maid? Discourses on Gender Equality, Work and Integration in Nordic Policy Debate.” $\begin{array}{llll}\text { Vienna: } & \text { QUING }\end{array}$ http://www.quing.eu/files/WHY/kvist_carbin_harjunen.pdf

Lewis, Jane. 2006. "Work/Family Reconciliation, Equal Opportunities and Social Policies: The Interpretation of Policy Trajectories at the EU Level and the Meaning of Gender Equality.” Journal of European Public Policy 13 (3): 420-37.

Lombardo, Emanuela. 2005. "Integrating or Setting the Agenda? Gender Mainstreaming in the European Constitution-Making Process." Social Politics 12 (3): 412-32.

Lombardo, Emanuela, and Maxime Forest. 2012. The Europeanization of Gender Equality Policies: A Discursive-Sociological Approach. Basingstoke: Palgrave.

Lombardo, Emanuela, and Petra Meier. 2006. "Gender Mainstreaming in the EU: Incorporating a Feminist Reading?” European Journal of Women's Studies 13 (2): $151-66$.

Lombardo, Emanuela, and Petra Meier. 2008. "Framing Gender Equality in the European Union Discourse.” Social Politics 15 (1): 101-29. 
Lombardo, Emanuela, Petra Meier, and Mieke Verloo (eds.). 2009. The Discursive Politics of Gender Equality: Stretching, Bending and Policymaking. London: Routledge.

Lycklama à Nijeholt, Geertje. 1987. "The Fallacy of Integration: the UN Strategy of Integrating Women into Development Revisited." Netherlands Review of Development Studies 1 (1): 23-37.

Lycklama à Nijeholt, Geertje, Virginia Vargas, and Saskia Wieringa (eds.). 1988. Women's Movements and Public Policy in Europe, Latin America and the Caribbean. New York: Garland.

Lovenduski, Joni (ed.). 2005. State Feminism and Political Representation. Cambridge: Cambridge University Press.

Mahon, Rianne. 2009. “The OECD's Discourse on the Reconciliation of Work and Family Life." Global Social Policy 9 (2): 183-204.

Mahon, Rianne, and Sonya Michel (eds.). 2002. Child Care Policy at the Crossroads: Gender and Welfare State Restructurings. New York: Routledge.

Mazey, Sonia, (ed.). 2000. "Introduction: Integrating gender." Intellectual and 'Real World' Mainstreaming." Journal of European Public Policy 7 (3): 333-45.

Mazey, Sonia. 2002. "Gender Mainstreaming in the EU: Delivering on an Agenda?" Feminist Legal Studies 10 (3-4): 227-40.

Mazur, Amy. 2002. Theorizing Feminist Policy. Oxford: Oxford University Press.

Mazur, Amy, and Mark Pollack. 2009. "Gender and Public Policy in Europe: An Introduction." Comparative European Politics 7 (1): 1-11. 
McBride Dorothy, and Amy Mazur, (eds.). 2010. The Politics of State Feminism: Innovation in Comparative Research. Philadelphia: Temple University Press.

McGauran, Anne-Marie. 2009. "Gender Mainstreaming and the Public Policy Implementation Process: Round Pegs in Square Holes?" Policy and Politics 37 (2): 215-33.

Meier, Petra. 2007. "Involving Private Actors in Policy-Making: Reflections on Gender Mainstreaming and Governance." In Politics Beyond the State. Actors and Policies in Complex Institutional Settings, eds. Kris Deschouwer and Theo Jans. Brussels: VUB press, 217-34.

Meier, Petra, and Karen Celis. 2011. "Sowing the Seeds of its Own Failure. Implementing the Concept of Gender Mainstreaming." Social Politics 18 (4): 469-89.

Meyers, Marcia K., Janet C. Gornick, and Laura R. Peck. 2001. "Packaging Support for Low Income Families: Policy Variation across the U.S. States.” Journal of Policy Analysis and Management 20 (3): 457-86.

Molyneux, Maxine. 1985. "Mobilisation Without Emancipation: Women's Interests, State and Revolution in Nicaragua." Feminist Studies 11 (2): 227-54.

Molyneux, Maxine, and Shahra Razavi. 2003. Gender Justice, Development and Rights. Oxford: Oxford University Press.

Morgan, Kimberly J., and Kathrin Zippel. 2003. "Paid to Care: The Origins and Effects of Care Leave Policies in Western Europe.” Social Politics 10 (1): 49-85.

Moser, Caroline. 1993. Gender Planning and Development: Theory, Practice and Training. New York: Routledge. 
Mukhopadhyay, Maitrayee. 2004. "Mainstreaming Gender or 'Streaming' Gender Away: Feminists Marooned in the Development Business." Institute of Development Studies 35 (4): 95-103.

Orloff, Ann. 1996. "Gender in the Welfare State." Annual Review of Sociology 22: 1-28.

Orloff, Ann. 2009. "Gendering the Comparative Analysis of Welfare States: An Unfinished Agenda." Sociological Theory 27 (4): 317-43.

Orloff, Anne, Julia O’Connor, and Sheila Shaver. 1999. States, Markets, Families: Gender, Liberalism and Social Policy in Australia, Canada, Great Britain and the United States. New York: Cambridge University Press.

Orloff, Ann, and Bruno Palier. 2009. "The Power of Gender Perspectives: Feminist Influence on Policy Paradigms, Social Science, and Social Politics." Social Politics 16 (4): 405-12.

Outshoorn, Joyce (ed.). 2004. The Politics of Prostitution. Cambridge: Cambridge University Press.

Outshoorn, Joyce, and Johanna Kantola (eds.). 2007. Changing State Feminism. Basingstoke: Palgrave.

Overholt, Catherine, Mary B. Anderson, Kathleen Cloud, and James E. Austin. 1985. Gender Roles in Development Projects: A Case Book. West Hartford, CT: Kumarian Press.

Pruegl, Elisabeth. 2009. "Does Gender Mainstreaming Work? Feminist Engagements with the German Agricultural State." International Feminist Journal of Politics 11 (2): 174-95. 
Rai, Shirin. 2008. The Gender Politics of Development: Essays in Hope and Despair. London: Zed books.

Rai, Shirin (ed.). 2010. "Special Issue on Ceremony and Ritual in Parliament." Journal of Legislative Studies 16 (3): 201-409.

Rao, Aruna, Mary B. Anderson, and Catherine A. Overholt. 1991. Gender Analysis in Development Planning: A Case Book. West Hartfort, CT: Kumarian Press.

Rees, Teresa. 2005. "Reflections on the Uneven Development of Gender Mainstreaming in Europe.” International Feminist Journal of Politics 7 (4): 555-74.

Rees, Teresa. 1998. Mainstreaming Equality in the European Union: Education, Training and Labour Market Policies. London: Routledge.

Sainsbury, Diane. 1996. Gender, Equality and welfare States. Cambridge: Cambridge University Press.

Sapiro, Virginia. 1986. "The Gender Basis of American Social Policy." Political Science Quarterly 101 (2): 221-38.

Savage, Michael, and Anne Witz. 1992. Gender and Bureaucracy. Oxford: Blackwell.

Saxonberg, Steven, and Tomas Sirovatka. 2006. "Failing Family Policy in PostCommunist Central Europe.” Journal of Comparative Policy Analysis: Research and Practice 8 (2): 185-202.

Shaw, Jo. 2000. "Importing Gender: The Challenge of Feminism and the Analysis of the EU legal order." Journal of European Public Policy 7 (3): 406-31.

Shiva, Vandana. 1989. Staying Alive: Women, Ecology and Development. London: Zed Books. 
Smith Mark, and Paola Villa. 2010. "The Ever-Declining Role of Gender Equality in the European Employment Strategy.” Industrial Relations Journal 41 (6): 526-43.

Squires, Judith. 2005. "Is Mainstreaming Transformative? Theorising Mainstreaming in the Context of Diversity and Deliberation.” Social Politics 12 (3): 366-88.

Stetson, Dorothy McBride. 2004. Women's Rights in the U.S.A.: Policy Conflict and Gender Roles, 3d ed. New York: Garland/Routledge.

Stetson, Dorothy McBride, and Amy Mazur (eds.). 1995. Comparative State Feminism. Thousand Oaks, CA: Sage.

Stratigaki, Maria. 2004. "The Cooptation of Gender Concepts in EU Policies: The Case of 'Reconciliation of Work and Family."' Social Politics 11 (1): 30-56.

Stratigaki, Maria. 2005. "Gender Mainstreaming vs Positive Action: An On-Going Conflict in EU Gender Equality Policy." European Journal of Women's Studies 12 (2): 165-86.

Subrahmanian, Ramya. 2004. "Making Sense of gender in Shifting Institutional Contexts: Some Reflections on Gender Mainstreaming." Institute of Development Studies 35 (4): 89-94.

Tiessen, Rebecca. 2005. "What's New about Gender Mainstreaming? Three Decades of Policy Creation and Development Strategies." Canadian Journal of Development Studies 26: 705-20.

Tinker, Irene (ed.). 1990. Persistent Inequalities: Women and World Development. New York: Oxford University Press.

Tinker, Irene, and Michele Bo Bramsen. 1976. Women and World Development. Washington, DC: Overseas Development Council. 
Tripp, Aili Mari. 2013. "Political Systems and Gender". In The Oxford Handbook on Gender and Politics, eds. Georgina Waylen, Karen Celis, Johanna Kantola and Laurel Weldon. Oxford: Oxford University Press, 514-35.

True, Jacqui, and Michael Mintrom. 2001. "Transnational Networks and Policy Diffusion: The Case of Gender Mainstreaming.” International Studies Quarterly 43 (1): $27-57$.

Van der Vleuten, Anna. 2007. The Price of Gender Equality: Member states and Governance in the European Union. Aldershot: Ashgate.

Verloo, Mieke. 2001. "Another Velvet Revolution? Gender Mainstreaming and the Politics of Implementation.” IWM Working Paper 5/2001. Vienna: IWM.

Verloo, Mieke. 2005. "Reflections on the Concept and Practice of the Council of Europe Approach to Gender Mainstreaming." Social Politics 12 (3): 344-65.

Verloo, Mieke (ed.). 2007. Multiple Meanings of gender Equality: A Critical Frame Analysis of Gender Policies in Europe. Budapest: CPS Books.

Verloo, Mieke, and Conny Roggeband. 1996. "Gender Impact Assessment: the Development of a New Instrument in the Netherlands." Impact Assessment 14 (1): $3-21$.

Verloo, Mieke, and Sylvia Walby. 2010. "Deliverable No. 71: Final WHY Report." Vienna: QUING Project. Available at http://www.quing.eu/files/deliverables/D71.pdf

Villagómez, Elisabeth. 2004. “Gender Responsive Budgets: Issues, Good Practices and Policy Options." Paper presented at the regional symposium on mainstreaming 
gender into economic policies, Geneva, UN Economic Commission for Europe, January $28-30$.

Walby, Sylvia. 2005. "Gender Mainstreaming: Productive Tensions in Theory and Practice.” Social Politics 12 (3): 321-43.

Walby, Sylvia. 2009. Globalization and Inequalities: Complexity and Contested Modernities. London: Sage.

Waylen, Georgina. 2007. Engendering Transitions: Women's Mobilization, Institutions and Gender Outcomes. Oxford: Oxford University Press.

Woodward, Alison. 2003. "European Gender Mainstreaming: Promises and Pitfalls of Transformative Policy Making." Review of Policy Research 20 (1): 65-88.

Woodward, Alison. 2004. "Building Velvet Triangles: Gender and Informal Governance." In Informal Governance in the European Union, eds. Thomas Christiansen and Simona Piattoni. Cheltenham, UK: Edward Elgar, 76-93.

Woodward, Alison, and Petra Meier. 1998. "Gender Impact Assessment: A New Approach to Changing Policies and Contents of Citizenship?" In Shifting Bonds, Shifting Bounds: Women, Mobility and Citizenship in Europe, eds. Virginia Ferreira, Teresa Tavares and Sílvia Portugal. Oeiras: Celta Editora, 95-105.

Zippel, Kathrin. 2006. The Politics of Sexual Harassment: A Comparative Study of the United States, the European Union and Germany. Cambridge: Cambridge University Press. 
i This introduction largely stems from the chapter 'Policymaking' for the Handbook on

Gender and Politics edited by Georgina Waylen, Karen Celis, Johanna Kantola and Laurel Weldon (Oxford University Press, 2013). 